\title{
Chapter 6 \\ The Mexican Case: The Differences between Autonomy and Radical Feminism
}

\section{Why Mexico Is an Interesting Case}

The surrogacy market in Mexico has grown since 2012, especially in the state of Tabasco, and in the last decade there have been several attempts to regulate the practice. At the time being there is no Federal law on surrogacy, ${ }^{1}$ and at a State level surrogacy is regulated only in the states of Tabasco and Sinaloa, whereas surrogacy agreements/contracts are explicitly considered invalid in the state of Coahuila where the Civil Code provides (art. 491) that the mother is the one who gives birth (Esparza \& Hernandez, 2014). Surrogacy is also illegal in the state of Querétaro.

In the last 7 years, the national debate and international attention towards surrogacy in Mexico have intensified and the discourse on the need to regulate has gained increasing visibility. Surrogacy is an emerging concern in Mexican feminism: a few women's groups in Mexico City mobilize on this issue, some asking for a proper regulation and others demanding a ban. This made Mexico an interesting case for a study on surrogacy politics: not only has this practice boomed in recent years but restrictive regulations were also introduced in the state of Tabasco in 2016 following this boom. In addition, there are ongoing discussions on whether and how to regulate the practice at a Federal level. It is also interesting that out of the three countries that I explore in my research, Mexico is the only one where surrogacy has developed primarily as a form of reproductive labour for women delivering babies most of all for foreigners. The Mexican market is shaped by the geographical proximity with the United States, which is the hub of international fertility industry. Of the three case studies, Mexico is also the country where women are more vulnerable to pervasive poverty, trafficking, violence, adolescence pregnancy, maternal mortality, and denial of legal and safe abortion.

\footnotetext{
${ }^{1}$ On a political level, Mexico is actually a Federation of States, and, at this time, there is no law which regulates surrogacy at a Federal level.
} 
Another aspect that makes this country interesting is that Mexican feminism is very active and variegate, with it being well-known internationally for the fight against feminicidio (femicide). How does Mexican feminism make sense of surrogacy? Is it a marginal issue when compared to the plague of violence and poverty? Do they frame reproductive labour as a form of violence or as an opportunity of empowerment? Does the issue intersect with the demand of legal abortion? Before addressing these points by entering into the details of the field-work, I would like to spend a few paragraphs to retrace the main initiatives that were carried out in an attempt to legalize and regulate a field that was spreading with no adequate rules and controls.

\section{History of Regulatory Attempts}

The surrogacy market in Mexico has developed, especially in the state of Tabasco, since 2012-2014 when Thailand and India, the two world leaders in low-cost surrogacy market, started to introduce restrictions with the aim to counteract an uncontrolled expansion that would have turned the countries into the "world's womb", to borrow a vivid expression used by Wanlop Tankananurak, a member of Thailand's National Legislative Assembly. ${ }^{2}$

The state of Tabasco established on the international surrogacy market as the new "Eldorado" for different reasons. First of all, because in 1997 it was introduced in the Civil Code (art. 92) a provision on cases of babies born from surrogacy: the article said that in the case of gestational surrogacy (when the surrogate is not the biological mother) the mother of the child is the one who ordered it, whereas in the case of traditional surrogacy (when the carrier is also the biological mother) the transfer of parental rights is to be processed as a full adoption. This article opened the door to the surrogacy industry and did not provide adequate regulation, as occurred in the state of Sinaloa where "the regulation of surrogacy was introduced in 2013" and "its restrictive legislation, particularly in regards to same-sex couples and non-Mexicans, has largely prevented the state from becoming a surrogacy destination with the political, judicial and media presence of Tabasco" (GIRE, 2017, p. 7). Besides legislation, another conducive factor for the development of surrogacy in Tabasco was the geographical proximity with the Yucatan peninsula, which at the same time is a territory with a large portion of indigenous population and migrants (from indigenous communities of other Mexican States such as Chiapas, and from other countries such as Guatemala, Ecuador, and Honduras; part of the migrant groups in Mexico are directed to the United States) as well as a popular tourist destination from the United States and other countries (with Cancun in Quintana Roo as the main hub for international flights and tourist accommodations) (Olavarría, 2019). Surrogates

\footnotetext{
${ }^{2}$ Reported by ABC https: //www.abc.net.au/news/2015-02-20/thailand-bans-surrogacy-for-for eigners/6163810
} 
are not only from indigenous and migrant groups: according to Olavarrìa surrogates belong to the low middle class, and are housewives, police officers, accountings, nurses, supervisors in factories, unemployed, and university students.

The laboratory procedures are often carried out in fertility clinics in Mexico City, whereas the birth takes place in Villahermosa, the capital of Tabasco; surrogates are recruited by surrogacy agencies, often foreigners, which advertise on the Internet the recruitment criteria and in some cases also arrange the hospitalization of pregnant women in rented houses. Agencies are not necessarily registered in the country, their legal site can be in the countries where the "demand" comes from, while they work in partnership with medical equips, lawyers, and psychologists in the countries where the "offer" of reproductive labour is higher (Olavarría, 2019). Most of the clinics operating in 2016 resulted not being registered in the Federal Commission for the Protection from Health Risks (COFEPRIS), only 1 of the 83 legal clinics registered across the country was in Tabasco. ${ }^{3}$

The uncontrolled development of the surrogacy industry raised concerns about the need to protect women from wrongdoings, exploitation, fraud, and abandonment of children. ${ }^{4}$ A resentment with gender-nationalist flavour also mounted: "Mexican women are exploited by foreign men" is a recurring phrase I encountered during my field-work. The United Nations Committee on the Rights of the Child in 2015 reported that "the regulation on surrogacy in the State of Tabasco not providing sufficient safeguards to prevent its use as a means to sell children" (United Nations Committee, 2015, p. 19).

This situation led to the introduction in 2016 of a restrictive legal reform aimed at containing the spread of surrogacy in the state of Tabasco and related abuses. The reform established that only Mexican citizens (included Mexican nationals living abroad), married or cohabitants, are allowed to sign surrogacy contracts with local surrogates, with no mediation from any third parties (agencies); surrogates must be between 25 and 35 years old, be in good health condition, not having been pregnant in the previous 365 days, and they cannot serve as surrogates more than twice; moreover, it has been established that the intentional mother must provide evidence of any medical conditions that hinder her to carry out a pregnancy and she must be between 25 and 40 years old. The reform also established the obligation to inform the local Health Secretary and Civil Registry and to deposit the contract at the Public Notary; it was also provided that no more than 2 embryos can be implanted and that a

\footnotetext{
${ }^{3}$ Vitela, N. (2016). Acusan descontrol en renta de úteros. Carece Tabasco de padrón de clínicas y médicos autorizados. Rechaza Cofepris tener competencia para supervisar la subrogación. Réforma, 3 january 2016, p. 2.

${ }^{4}$ An extract from the press (translated from Spanish): "Because of the benevolent law in Tabasco, women who rented their wombs, also to foreigners, contracted HIV, were abandoned and cheated. In some cases, surrogate mothers changed their minds once the baby was born and this resulted in legal battles. In other cases, homosexual intended parents had to fight extensive litigations to obtain the registration of the child. Also, there was rumours about the possibility that criminal organizations in international trafficking was benefiting from the Tabasco law" https://laverdadnoticias.com/ quintanaroo/Cancun-el-paraiso-para-alquiler-de-vientres-20190413-0123.html
} 
doctor must verify that the surrogate does not put in danger the well-development of the foetus (GIRE, 2017). Despite the restrictions, there are diffused concerns that irregularities still occur and that the new rules are bypassed: a common thought is that since the request for children cannot be satisfied in a legal manner, it would find other less transparent ways and this would render women and children even more vulnerable to trafficking and abuses.

The situation in Tabasco also sparked law proposals in the National Parliament: Senator Mely Romero Celis and other members of the Partido Revolucionario Institucional (PRI) Parliamentarian group presented on 13 October 2015 an integration to the General law on health (art. 61 Ter and 462 Ter), approved by the Senate on 26 April 2016 but later sent back to the House of Representatives for further discussion (Albornoz \& González, 2017). This reform would have enabled access to surrogacy only to married or cohabitant couples, heterosexuals, Mexicans, and with medical incapacity to procreate.

On 1 March 2016, Deputy Sylvana Beltrones Sanchez presented a different proposal which would have introduced an additional requirement: between surrogate and intended parents there must be a family connection. In the same year, on 24 March 2016, a roundtable on surrogacy was held by the National Commission for Human Rights which gathered together policy makers, judges, scholars, international organizations, and the civil society.

Years before this debate, another attempt to regulated surrogacy was advanced in the Federal District (since 2016 called Mexico City), which stands out on the national scene for its progressive policies for women, including for the 2008 law on abortion. Maricela Contreras Julian, representative of centre-left party Partido de la Revolución Democrática (PRD) and at that time President of the Health Commission, presented a law on surrogacy which established the following conditions: the embryo must belong to a heterosexual married or cohabitant couple, with proven medical impairment to procreate, surrogacy cannot be remunerated, the surrogate must be in good health and both parents and surrogates must live in the Federal District; it also provided the establishment of a surrogacy birth registry. Aimed at fighting against the trafficking of children, this proposal received consensus but in 2010 it was declared invalid for being discussed beyond the constitutional time.

Nearer to the present, the last proposal on medically assisted reproduction is authored by Senator Olga Maria Del Carmen Sanchez Cordero Davila (Sanchez Cordero's Bill from now on). This Bill provides for the establishment of a national registry of assisted reproduction, it provides that services are accessible to infertile and same-sex couples. The Bill also establishes sanitary requirements for clinics, prohibition for cloning and eugenics, 1-8 year of limitation of liberty for those who carry out assisted reproduction without the consent of the woman, and punishment for obtaining gametes and embryos illegally. In the explanatory memorandum of the text, (which is almost identical to the one presented by Romero Celis in 2016), surrogacy is mentioned as one of the techniques of assisted reproduction which, as the text specifies, enable millions of people to satisfy their desire for an offspring; on the other hand, in the text of the law (nor in the explicative memorandum part) 
surrogacy does not appear. However, there is widespread concern that this law would endorse surrogacy and open up the path for legalization.

\section{The Research Journey in Mexico}

I started to prepare for the field-work by selecting articles on surrogacy in the Mexican national press to understand the collocation of surrogacy in the broader political/public sphere as well as to identify women groups and other discourse players that I would reach out as interviewees in the following stage of the research. From preliminary contacts with a few informants in the country I understood that surrogacy was an emerging topic of debate for some feminist groups in Mexico City while it seemed that in the state of Tabasco there had not been a similar phenomenon I could investigate on: therefore, I decided since the start of my case study to focus on the national debate. I performed a keyword search "maternidad subrogada" on the following principal national newspapers: El Universal, Reforma, La Jornada. I also updated the search and the analysis of the press after the conclusion of field-work in May 2019 insofar the debate was ongoing. I found in total 79 articles (including duplicates): 60 on Reforma (since 2004), 10 on La Jornada (since 2015), and 9 on El Universal (since 2014). For the thematic analysis I only considered the most relevant articles published since 2015 (a total of 28), whereas I used the remaining articles to become familiar with the Mexican context and prepare the field-work.

From this preliminary exploration of the press, it emerged that surrogacy in Mexico is debated as a social problem and a topic of policy making, and that its media portrayal is constructed through the voices of politicians and institutional representatives, experts (academics and lawyers), and social movements (e.g. feminists, child's rights, and LGBTQ). Articles focus (or mention) the issue of the legal reform on surrogacy in Mexico (either federal and focused on the state of Tabasco), the political debate around the necessity to regulate it (or prohibit), the surrogacy industry and agencies practices, and problematic aspects of the practice (e.g. health risks, the legal limbo in which intended parents and babies were trapped after the reform in Tabasco, uncontrolled agencies, exploitation of vulnerable women, etc.). Only 5 articles did not fall into these subjects: one was about a surrogate baby born in China from the gametes of his dead parents, one was about gay parents in Spain, and 3 articles informed about surrogacy and international celebrities. This was a quite different picture from the one that resulted from the analysis of the American press where surrogacy seemed to be debated not as a problematic issue that the institution needs to tackle but rather as a viable process to have babies through technology and altruism of strong women.

My very first contact with the civil society was with the Feministas Mexicanas contra Vientres de Alquiler (Femmva): they invited me to speak at one of their public conferences in November 2018 in Mexico City. Since my stay in Mexico City, I closely followed activities undertaken by this young feminist collective, such as the preparation of an appeal to the Secretaria de Governacion Olga Sanchez Cordero and 
media relations. Through Femmva's facilitation and the visibility, I received among their network after the public conference I came into contact with other feminists in Mexico City and also organized a short mission to Villahermosa, the capital of Tabasco.

In Mexico City, I also participated as an observant to a feminist march against Violence against Women (VAW), a seminar on bioethics and gender at the Universidad Nacional Autonoma de México (UNAM), presentation of a book on surrogacy by a Mexican academic, and at the Foro México Unido por los Valores y la Familia organized by the Senate's Commission on Health. I interviewed 21 informants including 10 feminists, 2 child's rights activists, 3 public officials, 3 academics, 2 lawyers, and 1 politician. Pro-life and pro-family activists did not reply to my several invitations to participate. I conducted a frame analysis on the 21 interviews scripts and on some additional texts, including the explanatory memorandum of the Sanchez Cordero's Bill, 1 article by a prominent journalist engaged in child trafficking, ${ }^{5} 1$ feature article by international scholars with expertise on surrogacy in Mexico, ${ }^{6}$ the Grupo de Información en Reproducción Elegida's report (GIRE, 2017), 1 opinion paper written by one of GIRE's expert, ${ }^{7} 1$ feature article in a leftist magazine, ${ }^{8}$ a published interview to Maricela Contreras Julian, ${ }^{9}$ and a TV-interview to feminist Marta Lamas. ${ }^{10}$

\section{Surrogacy in the Press: A Problematic Social Issue to Be Tackled by the State}

The picture that I got by analysing press articles is that surrogacy in the Mexican public/media discourse is recognized as a social problem that institutions are asked to tackle: the press coverage is focused on the legal and social aspects of surrogacy, and the articles are related to the institutional/political activity (e.g. the reform in Tabasco, roundtables, law proposals and comments, presentation of studies and report, press conferences). Surrogacy is presented to the public opinion as a problematic practice which creates controversies, for instance, on whether foreigners should use Mexican women to have babies, homosexual couples should have babies through surrogacy, surrogacy is exploitation of women or an opportunity of revenue. It is also discussed as a practice that exposes women especially but also intended parents and children to several risks. Among the risks mentioned: in the case of

\footnotetext{
${ }^{5}$ https://aristeguinoticias.com/2906/mexico/uteros-en-alquiler-articulo-de-lydia-cacho/

${ }^{6}$ opendemocracy.net/beyondslavery/carolin-schurr-laura-perler/trafficked-into-better-future-whymexico-needs-to-regulate

${ }^{7}$ https://www.letraslibres.com/mexico/revista/gestacion-subrogada-no-abolir-el-debate

${ }^{8} \mathrm{https} / / / \mathrm{www}$.animalpolitico.com/2018/12/gestacion-subrogada-morena-regulacion/

${ }^{9} \mathrm{http}: / /$ mexicofertil.com/gestacion-subrogada-entrevista-con-la-diputada-maricela-contreras

${ }^{10} \mathrm{https} / / /$ noticieros.televisa.com/videos/gire-presenta-documental-de-flavio-florencio-deseos/
} 
medical complications surrogates are likely to receive poor assistance; the risk that intended parents do not take the children and abandon them and the surrogate; the risk of malformation for children born through medically assisted reproduction and surrogacy; the risk that surrogates are not paid; the risk that the child stays in a legal limbo without a nationality and access to health and social services.

In the press coverage on surrogacy, the State is accountable to mediate between the different requests and rights (e.g. rights to family formation and obligation to protect vulnerable women from exploitation) by regulating a sector which is at the moment characterized by arbitrary procedures, a lack of quality standards, violation of human rights, and permeability to criminal organizations.

Surrogacy agencies are given centrality in the media portrayal: they are often described as those who control the process and the industry, as foreigners, working in an unregulated manner, money makers who take advantage of poor women (paid less compared to the amount of money spent by intended parents).

Surrogacy is described as a reproductive technique and service, as a form of reproductive exploitation, as womb for rent (vientre de alquiler), as a form of commodification of children and violation of their human rights, as a form of commercialization of life, as a form of trafficking, as the only way to have a baby for homosexuals and women unable to carry on a pregnancy, as an international and unregulated market/business, and as an increasing and spreading practice. The following recurring arguments concur to the negative portrayal of surrogacy: the exploitation of women, the legal incertitude for babies, the health risks for surrogates and babies. On the other hand, the description of surrogacy as a scientific procedure, and as a way to family formation concur to the positive portrayal of surrogacy, which just needs to be better regulated to avoid the problems earlier introduced.

Surrogates are associated to the following characteristics: as women who are poor, often indigenous but also from urban areas such as Mexico City; women who are vulnerable and incapable to understand the contracts, with lack of employment opportunities and thus who rent their womb for money. Surrogates are described as women who are asked to follow all sorts of contract requests (such as aborting, refraining from colouring their hair, or having intercourse), whose health and psychological status can be affected (e.g. infertility, abortion, post-birth depression) and who are paid very little money for their service.

Intended parents are qualified mainly as foreign homosexuals, couples and singles, and as infertile Mexican couples. They are also portrayed as subjects with the right to have babies, whose rights are violated by restrictive and discriminatory laws or bureaucratic incertitude. They are described as people who can afford to pay for surrogacy, thus wealthier than the Mexican surrogates.

The child is described as a subject whose rights are violated, by the very fact of being generated through surrogacy insofar this is a form of commodification, or by restrictive legal frameworks and institutional initiatives. The child is also represented as vulnerable of abandonment, trafficking, and health risks. In the analysed press coverage, the relationship between the surrogate and the child is not described. 


\section{Principal Discourse Makers in Mexican Civil Society}

GIRE is the most expert organization in the debate on surrogacy and it strongly advocates for its regulation. It is a feminist organization established in 1992, with professional staff, an office in Mexico City and receives funds from various sponsors, including from North American foundations. ${ }^{11}$ GIRE is specialized in the defence of reproductive rights and its guiding principles are the autonomy of women and the opposition to punitive and prohibitionist approach in women's issues. In the area of sexual and reproductive rights (especially for the legalization of abortion), GIRE works in alliance with other feminist NGOs but these partners seem not to be engaged in the specific area of surrogacy, which remains an exclusive competence of GIRE.

The organization had a leading role in debates about the surrogacy reform in the Mexican State of Tabasco, where it also intervened by providing legal support to intended parents, mostly same-sex couples, who found themselves trapped in a legal limbo after the law was passed in 2016. GIRE expressed strong perplexities on this restrictive reform of surrogacy in Tabasco, and in 2017 GIRE published a report (in Spanish and English) entitled Surrogacy in Mexico. The consequences of poor regulation, in which the urgency for better regulation to protect the subjects involved in surrogacy is strongly advocated. On the same topic, GIRE also produced a videodocumentary entitled Deseos (desires).

GIRE participates in consultation events at an international level such as those organized by the International Social Service (ISS) in Geneva and expert meetings organized by the United Nations. It also collaborates with American organizations such as the Center for Genetics and Society (CGS), which we have seen in previous chapter is one of the leading actors in the surrogacy regulation front.

While conducting my field-work, Femmva was the only vocal feminist voice against the legalization of surrogacy. However, it has been almost inactive since 2020, after completion of my field-work. As mentioned earlier, Femmva is a spontaneous group of feminists primarily active in Mexico City: it was founded in June 2017 as a secret Facebook group, which months later developed into a public group. It does not have NGO status and it relies on the active daily voluntary work of 5 women and some degree of engagement of 15 more. Femmva organized public conferences, engaged with the media, took public position on law initiatives, wrote a petition to the Senate asking to repeal a Bill (Sanchez Cordero's Bill on assisted reproduction) which would mean the green light for surrogacy. Femmva is part of the transnational campaign Stop Surrogacy Now but it is not involved in international round tables or in dialogue with international organizations. Femmva allied with the chapter for Latin America and Caribbean of the Coalition against Trafficking against Women (CATW-LAC).

\footnotetext{
${ }^{11}$ Information disclosed during an interview with GIRE and reported in the list of sponsor published in GIRE's report (GIRE, 2017, p. 3).
} 
More recently, while I am writing this book and thus after completion of my fieldwork CATW-LAC and a new Frente Nacional Feminista Abolicionista (FNFA) launched the Latin American Manifesto against reproductive exploitation, promoted by 96 organizations, to oppose any legislative initiatives in Central and South American countries aimed at legalizing or regulating what in the document is defined "wombs for rent": "an unambiguous manifestation of discrimination, violence and violation of the human and fundamental rights of women, girls and boys, is contrary to the provisions of the international conventions and treaties to which our countries are signatories and whose observance is mandatory by virtue of a constitutional mandate". ${ }^{12}$ This document is the outcome of weekly online meetings between the International Coalition for the Abolition of Surrogate Motherhood (ICASM), a feminist coalition founded in 2018 in France, (which we will encounter again in Chaps. 7 and 8) and a few feminist groups in Latin America.

Femmva once carried out a communication activity with the support of Early Institute, which is the most expert organization in Mexico opposing the spread of the practice and attempts of legalization. This institute is a child's rights think tank, it is not a feminist group and is perceived as a conservative organization. During the reform in Tabasco, Early Institute in Mexico City promoted the first awareness campaign on surrogacy on Twitter (\#ExplotaciondeMujeresconFinesReproductivos), through Billboards and public events, with the aim of alerting vulnerable women about a new type of reproductive exploitation as well as to mobilize politicians (Olavarría, 2019).

During my field-work, I came across another feminist abolitionist group called L'Escola. It is composed of a dozen activists engaged in helping women in disadvantaged communities to identify and pursue their life projects, to know their rights and empowerment opportunities. Activists sensitize Mexican women about the danger of being offered to birth babies for others and about the risks of surrogacy. L'Escola was established in 2015 in Mexico City from the encounter with a feminist lawyer from Spain and in 2017, it opened its headquarter in Spain as a non-profit international organization.

From these paragraphs, it is worth noting how there is a striking difference in structure and relevance between the two feminist organizations that at the time of my field-work I identified as representatives of the reformist and abolitionist demands. GIRE's staff is consulted by Mexican institutions, they participate in expert groups on assisted reproduction in Mexico and spoke at the UNAM's bioethics unit. GIRE's events have widespread visibility and its founder Marta Lamas is considered the most influential feminist in Mexico: she is also the founder of Sociedad Mexicana Pro Derechos de la Mujer Semillas, of Instituto de Liderazgo Simone de Beauvoir, of Debate Feminista journal, and a key figure in the de-penalization of abortion in Mexico City. The current Secretary of Government Sanchez Cordero (and author of the aforementioned Bill proposal) has been an ally of GIRE in abortion campaigns.

\footnotetext{
${ }^{12}$ Latin American Manifesto. (2020). https://drive.google.com/file/d/1VIHvt_iK4W2xYdWJT_ RQayb93YTfEg3/view
} 
On the other hand, Femmva is a spontaneous network with no professional staff and no funds, based on the voluntary work of a few women. Femmva does not have direct access to surrogates and therefore Femmva's understanding of personal stories of women is drawn from other informants, literature, and the media. Femmva's alliance with CATW-LAC, which do have offices, funds, professional staff, and an international network, has never formally been concretized. The collaboration with Early Institute, which is also a structured organization with resources and expertise, was carried out for one single activity and generated dissent among Femmva sympathizers because they were unavailable to negotiate their radical feminist identity by being publicly associated with a group known as conservative. These are all barriers for Femmva to effectively influence policy makers.

\section{Framing the Issue. Arguments on the Basis of Regulation and Abolition Demands}

As found in the American case, in analysing the different positions that characterize the Mexican debate on surrogacy, the two fronts of reformists and abolitionists emerge. The divergence of the two fronts resides mostly in the meaning given to surrogacy and on the recipes to counteract the risks: some see surrogacy as wrong per se insofar it is a form of exploitation of women and sale of children, others see surrogacy as an opportunity for women to cope with poverty and start a process of empowerment by expressing their free choice to use their body; the former believe that surrogacy should be abolished and the latter that it should be regulated.

Protection of women and children's rights is a common concern, however according to abolitionist surrogacy is per se a form of violation of those rights. Poverty is identified by both fronts as a major factor of the diffusion of surrogacy. Additionally, there is a shared concern about the vulnerability of women to abuse, fraud, and the possibility that they engage in contract requests they do not fully understand. While there is a consensus that widespread illegality might affect the surrogacy market and put participants at risk of violations, reformists believe that this risk can be minimized through adequate regulation and that prohibition would just contribute to rendering surrogacy a profitable illegal activity. This latter position, which is one of pragmatism is a core argument in reformist front. Both agree that the government should take action: regulating (enforcing and supervising on abuses and wrongdoings) or outlawing. Debate with the participation of the civil society and institutions, circulation of scientific and factual knowledge are needs emerging from both fronts.

The categories of reformists and abolitionists work well theoretically to systematize the debate and surrogacy politics but one needs to acknowledge that the line between the two fronts sometimes blurs: although there are a few expert organizations with clear-cut positions, other interviewees who are not at the forefront in the surrogacy debate express milder views. For example, some wish very strict limitations to discourage the use of surrogacy (by foreigners, by homosexuals, by everybody) and others aim at ensuring that surrogacy is arranged in a fair and safe way by 
all participants (parents, surrogates, agencies). There are those who want that surrogacy be undertaken only among relatives and friends outside the market, and those who endorse the need for regulation not because they agree in principle that surrogacy represents an expression of women's autonomy or that the desire of having a child should be pursued with any means and protected as a right. Rather, some think that surrogacy needs regulation so as to reduce the vulnerability of women and children and because they do not believe that prohibition could be an effective approach in a context like Mexico characterized by widespread illegality.

Having set these premises, let me summarize in the list below how surrogacy is framed by both fronts. Again, I adopt the concepts of diagnostic and prognostic frames to systematize the principal problems that are identified and the possible solutions. Later, I will describe in more depth the arguments on the basis of both regulatory and abolitionist demands.

Diagnostic frames applied by reformists:

- violation of rights of intended parents, women, and children is caused by heterogeneous regulatory frameworks (State by State and internationally) and poor regulation in contracts

- lack of regulation increases the risks of human rights violation and trafficking

- surrogates are vulnerable to abuse because of the lack of awareness, poverty, power imbalance between them and intended parents, as well as the conflicts of interest with agencies and health services that are paid by intended parents but are supposed to protect the well-being of surrogates too

- surrogate's autonomy is hindered in the case of intended parents' decision on selective abortion and also when agencies arrange the pregnancy by keeping surrogates in dormitories

- demand of babies from LGBTQ people is caused by an induced desire of family as a form of conformism with capitalist/patriarchal institutions

- lack of factual information, awareness, and reflection in society on surrogacy implications and procedures

- some interviewees think that the market is the main problem, while surrogacy would not be a problem if arrangements are made privately among friends and relatives

Prognostic frames applied by reformists:

- regulating surrogacy at a Federal level

- working on international guidelines

- ensuring access to surrogacy (to have babies and to engage in reproductive work) to everybody with no discriminations

- ensuring surrogates full expression of autonomy and control over pregnancy

- protecting surrogates from the eventuality that intended parents abandon the child

- protecting the child's right to identity, nationality and right to know their origin (including being born from a surrogate)

- arranging multiple payments during the pregnancy and not only at birth

- avoiding conflict of interest to protect the health and right of surrogates

- promoting research on the well-being of children and surrogates 
- establishing a national register of surrogate babies and surrogates

- institutional supervision over human rights violations

- fostering expert debate with the civil society and institutions

- some interviewees wanted that surrogacy is accessible only to: infertile Mexican couples, outside the market without intermediaries, with no employment of poor women

Diagnostic frames applied by abolitionists:

- surrogacy is a form of reproductive exploitation of women (also a new form of slavery) in which the industry (foreign and national) makes profit

- surrogacy is a form of commodification of women and children

- surrogacy is a form of sale of children (against international conventions)

- surrogacy prospers because of women's poverty, lack of work opportunities, low awareness on rights and early pregnancies

- surrogacy is the expression of patriarchy: male power takes advantage of female reproductive capacity, women have interiorized motherhood desire as normative femininity, women are socialized to competition rather than solidarity with other women, women take for granted that their bodies can be exploited

- surrogacy appears a problematic within a neoliberal culture where everything can be bought (including body, sexuality and persons)

- acceptance of surrogacy spreads also because selling children is a common practice in poor communities (children are given away to other families with the wish to give them a better future) and also for human trafficking

- politicians have connections with infertility industry

- widespread illegality is conducive of surrogacy prosperity and wrongdoings

- surrogacy causes psychological sufferance for the child and the surrogate

Prognostic frames applied by abolitionists:

- outlawing surrogacy

- fostering the debate through fora (roundtables, consultations) with the civil society and institutions and avoiding polarization along other reproductive and sexual issues (abortion, prostitution)

- information campaign on the risks, implications, and unsuccessful stories

- intervening on the structural causes of women's poverty and vulnerability: community-based economic and social development

- awareness campaign with disadvantaged women

- fostering international alliances to increase expertise and influence

In order to understand the argumentative basis of the widespread demand of regulation, I analysed more closely the position advocated by GIRE and the preamble of the Sanchez Cordero's Bill. I identify three core themes: one is that the achievement of parental desire should be pursued by all available means and therefore assisted reproduction technology should be widely accessible; the second theme is that women should be free to choose how to use their reproductive capabilities including to gestate for others. Both prescriptions are presented under the rubric of progress as the desirable direction of the modernization process: the 
State law needs to be updated to modern times to enable couples to achieve their parental desire through technology and to enable women to express their autonomy.

The third theme does not point at the ideal principles of social or individual aspirations, as the first two do, but argues that regulation is the only doable path insofar prohibition would fail to prevent that surrogacy becomes an illegal market: regulation and legalization would be the only effective way to protect women's rights since prohibition of surrogacy would on the contrary encourage illegality and trafficking and therefore would render women more vulnerable to abuses and exploitation. Pragmatism is also suggested as a recipe for the acceptance of structural female poverty and unemployment, conditions that cannot be eliminated but rather could be mitigated by giving women a new job opportunity: surrogacy. This approach emerges, for example, in the following article on Open Democracy: "A ban merely serves as a fig leaf to hide a demonstrable lack of engagement with the structural problems women, and particular single mothers, face in Mexico's neoliberal economy: lack of employment options, insufficient access to health care, non-enforceability of alimony payment of fathers, and a general lack of social benefits. There is a better way. Mexican State bodies and international organizations must work hand in hand to formulate, implement, and monitor regulations that ensure adequate living conditions and improve the legal situation of surrogate mothers in the transnational surrogacy industry [...] formulate and ensure the enhancement of policies that regulate and control the different actors in the surrogate business". 13

Considering now the first two themes in more detail: artificial procreation accessibility to fulfil parental desire and women's autonomy in using their bodies.

The Sanchez Cordero's law proposal on medically assisted procreation builds its arguments on the necessity to update existing laws according to available scientific and technological advancements, in order to enable a modernization process of the country, which is already occurring in other spheres of policy making such as education, economy, and energy. The explanatory memorandum of the law remarks that in the past the moral and psychological burden of infertility could not be alleviated due to a lack of knowledge of technological and diagnostic tools; however, nowadays technical solutions developed over the last 40 years (since the first test-tube baby Louise Brown was born in United Kingdom in 1978) enable to satisfy the desire of filiation and the human right of family formation. The law aims, through the regulation of medically assisted procreation, to ensure that citizens could access quality services. Access to these techniques is understood as an expression of decisional freedom in reproductive life, which is acknowledged by the Mexican Constitution since 1974 with specific reference to family planning. The law proposal explicitly presents itself as a necessary normative update to face issues that are typical of modern times, to guarantee the well-being of everybody, a goal that so far

\footnotetext{
${ }^{13}$ opendemocracy.net/beyondslavery/carolin-schurr-laura-perler/trafficked-into-better-future-whymexico-needs-to- regulate
} 
has been hindered by ideological positions, such as the attempt to acknowledge the juridical status of embryos.

The necessity to improve access to scientific advancements to achieve parental desire is also argued by GIRE: "assisted reproduction is an advancement of science, which is fundamental for the rights of everybody to have a family and for the rights of reproductive autonomy"; surrogacy is one of these techniques, which "helps people to exert their rights to have a family with the number of children they wish". ${ }^{14}$

The woman's autonomy principle is often highlighted in the definitions of surrogacy used by regulatory discourse makers: central is the independent role of woman in the decision on whether to participate in other people's reproductive process, by sharing her body. For example, in GIRE's report surrogacy is defined as "an arrangement in which a woman agrees to carry a pregnancy for another individual or couple who intend to parent the child born of this pregnancy" (italics mine) (GIRE, 2017, p. 9). The same position also emerges in the following extract written by one of GIRE's expert: "To criminalize surrogacy as a form of human trafficking means to suggest that women are unable to decide in an independent manner whether they want to gestate the product of others; it means to assume that there are always abuses and coercion and there is no free exercise of rights in surrogacy". "This form of "participation" according to GIRE is to be acknowledged from an economic perspective: "GIRE considers that the commonly-held narrative, suggesting that surrogacy must be undertaken for strictly altruistic reasons, is based on gender stereotypes and overlooks surrogates' reproductive autonomy" (GIRE, 2017, p. 13). In GIRE's videodocumentary Deseos a woman in Tabasco is interviewed: she is already a mother and divorced, she reports that she freely decided to become a surrogate as a project to gain enough money to open a small business and buy a motorbike. In a nutshell, surrogacy is presented as an opportunity for women, an opportunity which should not be limited: GIRE even interprets as discriminatory the age limit for serving as surrogate, which was set by the 2016 Tabasco reform.

The autonomy envisioned by the discourse described so far refers to a more intimate dimension, a sort of autonomy from emotions and physical bonds: the woman does not necessarily become attached to the baby she carries, therefore taking this assumption for granted is to be viewed as a symptom of conservatism and stereotyped femininity. This argument is conveyed by the following testimony: Marta Lamas, founder of GIRE, declared on Televisa that pregnancy should not be mystified, that there is nothing wrong in the decision of women to make babies for other couples, either heterosexual or homosexual, who want so much to become parents.

The perspective advocated by Femmva is the opposite: the core argument they use in opposing legalization attempts and spread of surrogacy in the country is that it implies the commodification of women whose body and reproductive capacity are

\footnotetext{
${ }^{14}$ Ramos, C. (2018). Gestación subrogada: Morena apuesta por regular en lugar de prohibir. Animalpolitico, 10 December. Retrieved from: https://www.animalpolitico.com/2018/12/ gestacion-subrogada-morena-regulacion/

${ }^{15}$ https://www.letraslibres.com/mexico/revista/gestacion-subrogada-no-abolir-el-debate
} 
exploited by the industry and intended parents, who are generally wealthier and more educated than surrogates. In Femmva's view, this market flourishes because of female poverty and Mexican women engage in reproductive labor because they live in disadvantaged social status and have little opportunity of employment. Surrogates are seen as vulnerable subjects, belonging to disadvantaged groups such as indigenous, poor, and migrants, often poorly educated and with a lack of awareness on their rights and opportunities to achieve life goals. In addition to poverty they are encouraged to work as surrogates by a patriarchal culture of female inferiority and disposability for sex and reproduction that they have for longtime absorbed.

The commodification frame advanced by Femmva (which also circulates among feminist abolitionists in other countries such as Spain, France, and Italy) resonates with feminist anti-prostitution campaigns and more broadly with the feminist discourse on gender-based violence against women (VAW). ${ }^{16}$ I would say that surrogacy is explained through the Marxist feminist theory of power, which explains women's status, VAW, and exploitation as structural phenomena due to the power imbalance between men and women embedded in patriarchy (Dutton \& Nicholls, 2005; Felson, 2002). Gender inequality is implied to be the common cause of lethal intentional violence, as well as sexual exploitation for pleasure and economic exploitation of gestational capacity. Motherhood and gestational capacity as a principal marker of femininity are seen as resources that male-dominated societies for centuries have attempted to control and make profit out of them. From this vantage point, Femmva believes that the best way to hinder reproductive exploitation is to eradicate structural inequality by promoting community-based social development, women's entrepreneurship (e.g. fair trade, handy-craft), and Statebased policies to give women work opportunities, education, and protection from abuse.

\section{A Principles-Driven and Polarized Debate: The Two Streams in Feminism}

By comparing GIRE and Femmva discourses, it emerges how they rely on irreconcilable principles about: how women should achieve emancipation and gender equality; prioritization of women's rights in relation to LGBTQ's rights; motherhood as a marker of female identity; to what extent structural inequality (female poverty) should be accepted or resolved and how. On a broader scale, the divergence between GIRE and FEMMVA reflects the theoretical frameworks of two major streams of feminism already introduced in the literature review in Chap. 3 (Farquhar, 1996; Rushing \& Onorato, 2003): radical and (neo)liberal.

\footnotetext{
${ }^{16}$ The discourse on gender-based VAW in Mexico has been for decades applied with emphasis on the so-called feminicidio, a national emergency of women being killed by men in contexts of criminal organization as well as domestic violence.
} 
Although streams of feminism can be classified in different ways and vary historically, the following definition of radical feminism can be adopted for the sake of clarity: "the acceptance of the existence of patriarchy alongside a commitment to end it; second, the use and promotion of women-only space as an organizing method; third, a focus on all forms of male violence against women and their role as a keystone of women's oppression broadly; fourth and finally, an extension of the analysis of male violence against women to include the institutions of pornography and prostitution" (Mackay, 2015). In talks and interviews conducted during the fieldwork those who identify themselves as radical feminists tend to remark that women are the political subjects of feminism, that sexual difference is constitutive of women's identity (by opposing the gender feminism who on the contrary believes that gender identity is totally self-determined), they remark the fact that women are subjugated in patriarchy, and they envision sisterhood and self-consciousness as a way to emancipation; while they believe that women should be fully in control of their body, they oppose recipes of emancipation based on self-commodification. Liberal feminism (also called equality feminism) originally pursued to reveal "the gendered exclusions within liberal democracy's proclamation of universal equality, particularly with respect to the law, institutional access, and the full incorporation of women into the public sphere" (Rottemberg, 2014, p. 419). Differently, the neoliberal feminism "offers no critique-immanent or otherwise-of neoliberalism" and "the neoliberal feminist subject is thus mobilized to convert continued gender inequality from a structural problem into an individual affair" (Rottemberg, 2014, pp. 419-420). ${ }^{17}$ Neoliberal feminism is also called autonomy feminism and often overlaps with gender feminism when it comes to themes of sexual/gender identity.

Femmva strongly positions its engagement against surrogacy within a radical feminist imperative and think that those who justify surrogacy in the name of women's autonomy are blind and complicit to women's commodification, and thus that they are not "real feminists". Femmva believes in autonomy as a central principle for women's emancipation but does not consider a form of autonomy the sale of sex and reproduction, which on the contrary they see a degrading activity that women do as last resort. Femmva's opposition to surrogacy not only pursues the goal of stopping the exploitation of women but also, through the pursuit of this goal, aims to reaffirm an authentic nature of feminism, which in their view is distorted and endangered by other kinds of "fake feminisms" who embrace cultural imperatives of self-exploitation.

On the other hand, neoliberal or autonomy feminists such as GIRE and its partners take a distance from Femmva's position since they believe that women's ownership over their body and over the decisions of using their unique reproductive

\footnotetext{
${ }^{17}$ Neoliberalism is a concept that has gained popularity in social sciences since the 1990s; it is a controversial term with very broad and incoherent definitions that vary depending from the vantage point and tend to be employed in critiques of existing capitalist structures and discourses. It points at an economic and social system as well as at a political ideology and experiment inscribed in late capitalism, laissez-faire, and free market, characterized by deregulation and privatization of the welfare state, commodification of everyday life, and centrality of individual free choice in the value system. (Ganti, 2014; Venugopal, 2015)
} 
resources to improve their social status, or simply to contribute to somebody else's desire of having a baby, should never be restricted. They call for the rights of women to decide on how to use their reproductive capacities, including gestating for others: the modern Mexican woman is capable of making informed choices for themselves, and she should not be hindered in their opportunity to ameliorate their economic status by taking the opportunities offered by different kinds of markets. We have seen how woman's autonomy also entails autonomy from emotions and physical bonds: it is believed that the woman does not necessarily become attached to the baby she carries, therefore taking this assumption for granted is viewed as a symptom of conservatism and stereotypization of femininity.

How important is surrogacy for Mexican feminism? Certainly, concern about women's vulnerability in surrogacy is increasing but, with the exception of those with specific expertise and ad-hoc activities (such as GIRE, Femmva, and CATWLAC among those organizations I got in contact), knowledge on surrogacy tends to be anecdotal or based on broader conceptual categories (such as women's rights and autonomy, exploitation of women, etc.) rather than on a detailed understanding of the practice (e.g. some do not know that surrogacy implies selective abortion and that often the surrogate has a little say in that, some do not know that the surrogate needs to be treated with drugs to prepare the body for the implant and that this also occurs in the so-called altruistic surrogacy, health risks for the child and surrogate are often ignored, the dimension of the industry is sometimes underestimated, etc.). The lack of diffused factual knowledge alongside an a-critical application of feminist frames such as commodification and autonomy (borrowed from other discourses such as prostitution and abortion) might be major factors contributing to the polarization of the debate between abolitionists and reformists; this polarization does not apply only within the feminist movement but is also shared by those who are in the process of building an opinion on the issue. In other words, the formation of consensus and dissent is heavily influenced by a passionate advocacy of principles, which work as orientation devices for activists who have not yet accumulated sufficient expertise on the topic and for the general public too.

Neoliberal feminists working in the sexual and reproductive field (who are potential discourse makers on surrogacy) tend to endorse woman's autonomy as a non-negotiable and absolute principle and to apply it to surrogacy as an a priori dogma, although they have accumulated only limited knowledge and reflection on what surrogacy concretely is and means for women. Emblematic of this tendency is the following testimony given by a feminist activist working at one of GIRE's partner organizations. The interviewee since the very start admitted that she does not have any direct experience or expertise on surrogacy, but she nevertheless accepted to interact with me to talk about reproductive issues in general. She was not aware of the details of surrogacy such as the selective reduction of multiembryos implantations. This lack of knowledge did not refrain from her expressing an a priori endorsement to the cause of regulation of surrogacy, uniquely in light of the unquestionable principle of the woman's autonomy, which leads all activities run by the NGO she works for: "If I decide to be a surrogate womb, it is my rights to use 
my body, make a contract and have that job and buy me an apartment faster than what I can do it by doing another kind of work. It is a means of work. It is the rights of people to choose, and this slogan works for everything: having a tattoo, deciding which part of your body you want to work with (hands, genitals or your wombs). You should be able to make your choice for yourself whereas the State should make the conditions for you to be cared for".

I found this same attitude, although with different levels of passions, in two other public officials and a few academics I interacted with during my field-work. These are the words of a public official in a governmental institution for women's empowerment, who had never been involved in any initiative regarding surrogacy; she built her own knowledge on the topic on a personal capacity and her main source has been the GIRE's report. "It is a complex issue, I don't know, personally I would say that regulation is needed because a woman has a right to her body. Just as she should have the right to terminate the pregnancy, she should also be able to lend her uterus".

We have seen earlier on when discussing the arguments on the basis of the regulatory demand that the women's autonomy principle intertwines with a broader discourse of modernization, which nowadays is a discourse with certain popularity and legitimization. Modernization is the core principle of the new government established in January 2019: Mexico deserves to become a modern country and this goal should be achieved through the emancipation of women, technological advancement, fight against criminality and illegality. Gender equality is a crucial theme in public expectations from this new political era and for the first time in the political history of Mexico, almost 50 percent of the Members of Parliament and of the Cabinet are women. It is worth noticing how access to safe and legal abortion is the number one cause of Mexican feminism and there are strong hopes that this goal will be achieved soon under this new government. Woman's autonomy is the theoretical base for feminist pro-choice demands of abortion legalization and we have seen in the American case that any limitation to the woman's autonomy is seen as a goal for the abortionist cause: since the pro-surrogacy discourse is deeply built right on the woman's autonomy principle, opposition to surrogacy is perceived as an obstacle to the full application of this principle. In the case of Mexico, I would recontextualize this thought by saying that the woman's autonomy principle is embraced often uncritically as an unquestionable priority to be achieved, and often invoked also by those who do not have any solid knowledge on surrogacy procedures and implications, as the principle for which surrogacy should be regulated.

\section{Suggestions to "Deradicalize" the Debate}

Building and circulating knowledge on surrogacy practices, procedures, implications, and testimonies is a priority to balance the present situation in which most of the expert information comes mainly from one feminist NGO and one child's rights think tank: many actors (in the civil society, academia, politics, public administration, and media) will sooner or later face the urgency to take a position and contribute in policy making and they are likely to face the inconsistencies of 
arguments based on theoretical principles. There is need for a debate, circulation of information and dialogue between institutions and the civil society: consultative working-groups would be a useful tool to inform policy makers in their attempts to regulate surrogacy. However, given the different vantage points of different actors it is preferable that arguments are based on literature and facts, as well as national and international cases and testimonies of surrogates and intended parents, rather than on broader principles, which might bring about the same polarization that it exists between feminists.

Feminist abolitionists need to strengthen their organization and influence on institutions and the wider public in order to balance a debate that at the moment is heavily influenced by regulatory positions and knowledge produced by feminist organization GIRE. Abolitionists have the opportunity to strengthen their role, access to institutions, and visibility among the wider public through strategic alliances with international actors such as the Stop Surrogacy Now campaign and ICASM (and indeed recent launch of Latin American Manifesto suggests that this strategy is being pursued) but also with national actor such as Early Institute and other organizations working on child's rights. An alliance with organizations that are positioned in the conservative spectrum would imply for feminists to put their ideological priority on the side and privilege the concrete goal of raising public awareness on the need to abolish surrogacy and influence policy makers towards it.

On a more ground level, there is a need to increase knowledge and awareness of vulnerable women groups about the possibility that they might be approached by agencies or other actors and offered to gestate for others: women need to be informed about the legal and health risks implied in this kind of work. This can be a very concrete area of engagement for feminist groups in Mexico.

As I will discuss broadly in Chap. 8, the child's rights perspective needs to be integrated in (Mexican) feminist abolitionist discourse: the frame of the commodification of women is weak in a pervasive culture of self-exploitation, but protection of children from commodification would be a more powerful argument. Feminism should acknowledge that surrogacy is fundamentally different from the debate on prostitution: surrogacy does not only involve an exploiter and an exploited, but there is a third subject being commodified and hurt, the child, who is detached intentionally at the very moment of birth from the body in which he started to develop and feel; the child is the only one with no choice and no agency among the subjects involved in surrogacy.

\section{References}

Albornoz, M. A. M., \& González, F. L. P. (2017). Marco normativo de la gestación por sustitución en México: Desafíos internos y externos. Revista del instituto de Ciencias Jurídicas de Puebla, 11(39), 9-23.

Dutton, D., \& Nicholls, T. L. (2005). The gender paradigm in domestic violence research and theory: Part 1-The conflict of theory and data. Aggression and Violent Behavior, 11(6), 680-714. 
Esparza, M. B., Hernandez, P. C., \& Alcocer, A. R. (2014). Maternidad Subrogada: Exploitacion de mujeres con fines reproductivos. Mujeres Independientes en Accion.

Farquhar, D. (1996). The other machine: Discourse and reproductive technologies. Routledge.

Felson, R. B. (2002). Violence and gender reexamined. American Psychological Association.

Ganti, T. (2014). Neoliberalism. Annual Review of Anthropology, 43(1), 89-104.

GIRE. (2017). Gestacion subrogada en México. Resultados de una mala regulacion.

Mackay, F. (2015). Radical Feminism. Theory, Culture \& Society, 32(7-8), 332-336.

Olavarría, M. E. (2019). La gestaciòn para otros en México. Parentesco, tecnologìa y poder. Gedisa.

Rottemberg, C. (2014). The rise of neoliberal feminism. Cultural Studies, 28(3), 418-437.

Rushing, B., \& Onorato, S. (2003). Controlling the means of reproduction: Feminist theories and reproductive technologies. Humanity and Society, 27(3), 393-413.

United Nations Committee on the Rights of the Child. (2015). Concluding observations on the combined fourth and fifth periodic reports of Mexico (CRC/C/MEX/CO/4-5).

Venugopal, R. (2015). Neoliberalism as concept. Economy and Society, 44(2), 165-187.

Open Access This chapter is licensed under the terms of the Creative Commons Attribution 4.0 International License (http://creativecommons.org/licenses/by/4.0/), which permits use, sharing, adaptation, distribution and reproduction in any medium or format, as long as you give appropriate credit to the original author(s) and the source, provide a link to the Creative Commons license and indicate if changes were made.

The images or other third party material in this chapter are included in the chapter's Creative Commons license, unless indicated otherwise in a credit line to the material. If material is not included in the chapter's Creative Commons license and your intended use is not permitted by statutory regulation or exceeds the permitted use, you will need to obtain permission directly from the copyright holder.

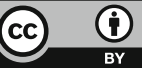

